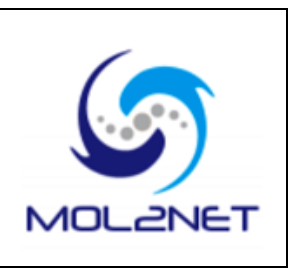

\title{
Study of acute toxicity of an aqueous abstract obtained from the flowers of Kigelia africana in Balb/c mice
}

\author{
Liset Alvaré Morfa ${ }^{1}$ *, Jorge Antonio Pérez Donato ${ }^{2}$, Enoel Hernández Barreto ${ }^{3}$ and \\ Sergio Sifontes Rodríguez ${ }^{4}$ \\ ${ }^{1}$ Department of Pharmacy. Faculty of Chemistry and Pharmacy. Central University "Marta Abreu" of \\ Las Villas, Road to Camajuaní Km. 5 1/2. Santa Clara. Villa Clara. Cuba； E-Mail: \\ enoelh@uclv.edu.cu \\ 2 Chemical Bioactive Center. Road to Camajuaní Km. 5 1⁄2. Santa Clara. Villa Clara. Cuba; E-Mails: \\ japdonato@uclv.cu; sifontes@uclv.edu.cu; \\ * Author to whom correspondence should be addressed; E-Mail: lamorfa@uclv.cu; \\ Tel.: 005342214804
}

Received: / Accepted: / Published:

\begin{abstract}
:
Kigelia africana is used in traditional medicine and toxicological effects of the different extracts of the fruit, bark of the stem and leaf but not of its flowers have been reported, so the present investigation aims to determine the toxic potential of the aqueous extract obtained from the flowers of Kigelia africana by the acute toxic class method in Balb/c mice. An aqueous extract of the flowers was obtained, which was administered orally at a single dose of 50,500 and $2000 \mathrm{mg} / \mathrm{kg}$ and three Balb/c mice of different sexes were used in each level. With the administration of 50 and $500 \mathrm{mg} / \mathrm{kg}$ doses, $100 \%$ survival was obtained, the daily systematic observations, the macroscopic analysis of the organs and their body weight showed no evidence of any sign of toxicity unlike the doses of $2000 \mathrm{mg} / \mathrm{kg}$ where the deaths were observed in 48 hours being the main clinical symptoms depression of the central nervous system and polyuria marked with signs and symptoms of dehydration. The product can be classified in category 4 .
\end{abstract}

Keywords: Kigelia africana; acute toxic class method; Balb/c mice; aqueous extract; toxicological effects.

\section{Introduction}

Kigelia africana (Lam.) Benth is an arboreal species that is currently gaining great interest since the experiments on the effect of its extracts and some of its pure compounds have corroborated its medicinal properties ${ }^{1}$. Toxicological effects of the different extracts of the fruit, bark of the stem and leaf but not of its 2. Results and Discussion

$K$. africana is a rich source of many chemical compounds as it is known in Bignoniaceae ${ }^{3}$ so many of its therapeutic activities and folkloric use flowers have been reported $^{2}$. So the present investigation aims to determine the toxic potential of the aqueous extract obtained from the flowers of Kigelia africana by the method of the acute toxic class in Balb/ c mice.

lies in this. The aqueous extract is the most commonly used in traditional African medicine and although the plant is not extremely toxic ${ }^{2}$ in 
our study the product can be classified in category 4. As a result of the administration of doses 50 and $500 \mathrm{mg} / \mathrm{kg}$, it was obtained $100 \%$ survival, the daily systematic observations, the macroscopic analysis of the organs and their body weight showed no evidence of any signs of toxicity, unlike the doses of $2000 \mathrm{mg} / \mathrm{kg}$ where only one male survived and the deaths were observed in the first 48 hours, the main clinical symptoms were depression of the central nervous system and marked polyuria with signs and symptoms of dehydration. The results of acute toxicity in this study were supported by Farah, et al in $2017^{4}$ who reported that the aqueous extract of the fruit administered orally in Wistar rats at a dose of 50, $500 \mathrm{mg} / \mathrm{kg}$ was well tolerated by the animals since there are no signs of toxicity such as restlessness, piloereccion, nasal or lacrimal secretions and non coordinated march. However, in $2000 \mathrm{mg} / \mathrm{kg}$, unlike ours, they obtained $100 \%$ survival of the animals, but presented alterations in the hematological and biochemical parameters where hepatorenal toxic effects were evidenced as in our work (Fig 1).

\section{Materials and Methods}

Fresh flowers of Kigelia africana were collected in the forest surrounding Botanical Garden of Central University of Las Villas. Phytochemical procedure: Aqueous extract (KPAE) was obtained by decoction. $50 \mathrm{~g}$ of dry flowers (powder) was boiled with distilled water $(500 \mathrm{ml})$ in a balloon for 10 minutes and then allowed to cool to room temperature. To determine the quality of the drug used, we proceeded according to the methods of quality control for herbal materials by the World Health Organization 5 , routinely applied in the Pharmaceutical Chemistry laboratory of the Faculty of Chemistry and Pharmacy of the Central University " Marta Abreu " of Las Villas.

\section{Conclusions}

The findings revealed that the aqueous extract of the leaves of $K$. africana in low doses was safe, but high dose can have hepatorenal toxic effects. More work is needed for the determination of LD50 as well as running a standard battery of toxicological tests since no single test is capable of providing the total safety of a product.

\section{References and Notes}

1. Bello, I.; Shehu, M. W.; Musa, M.; Asmawi, M. Z.; Mahmud, R., Kigelia africana (Lam.) Benth.(Sausage tree): Phytochemistry and pharmacological review of a quintessential African traditional medicinal plant. Journal of ethnopharmacology. 2016, 189: 253-276.
Male and female Balb/c mice from the National Laboratory Animal Producer Center (CENPALAB) were used, which were kept at 25 $\pm 2{ }^{\circ} \mathrm{C}, 12 / 12 \mathrm{~h}$ in a night / day cycle, with food and water ad libitum. Three dose levels of 50, 500 and $2000 \mathrm{mg} / \mathrm{kg}$ were evaluated and three Balb/c mice of different sexes were used in each level according to Organization for Economic Cooperation and Development (OECD) guidelines No.423 ${ }^{6}$. The aqueous extract was administered orally at a single dose and anatomopathological and weight studies were carried out. 
Mol2Net-04, 2018, BIOCHEMPHYS-01 (pages 1- x, type of paper, doi: xxx-xxxx http://sciforum.net/conference/mol2net-4 $\mathbf{3}$

2. Arkhipov, A.; Sirdaarta, J.; Rayan, P.; McDonnell, P.; Cock, I., An examination of the antibacterial, antifungal, anti-Giardial and anticancer properties of Kigelia africana fruit extracts. Pharmacognosy Communications 2014, 4 (3): 62-76.

3. Harborne, J., Methods of plant analysis. In Phytochemical methods, Springer: 1984; pp 1-36.

4. Farah, H. M.; El Hussein, A. M.; Khalid, H. E.; Osman, H. M., Toxicity of Kigelia africana Fruit in Rats. 2017, 12(6): 1-9.

5. OMS, B. M., Informe mundial sobre la discapacidad. Malta: World Health Organization 2011.

6. In, O. Acute oral toxicity-Acute oral toxic class method. Guideline 423; adopted 23/06/1996) Eleventh Addendum to the OECD guidelines for the testing of chemicals, Organization for Economic Co-operation and Development: Paris, 2001, accessed on 21st May, 2007, at http://www. research. murdoch. edu. au/ethics/arec/oraltoxicity: 2001. 